\title{
FOUR SPECIES OF CALOPLACA S.L. (LICHENIZED ASCOMYCOTA, TELOSCHISTACEAE) NEW FOR POLAND
}

\author{
KARINA WILK
}

\begin{abstract}
Four calcicolous species of the genus Caloplaca s.1., C. concreticola Vondrák \& Khodosovtsev, C. interfulgens (Nyl.) J. Steiner, C. isidiigera Vězda and C. scabrosa Søchting, Lorentsen \& Arup, representing various taxonomic groups, are reported as new for Poland, with brief taxonomic remarks and information on their habitat and distribution given.
\end{abstract}

Key words: biodiversity, Carpathians, distribution, mountains, Pyrenodesmia, taxonomy, Xanthocarpia

Karina Wilk, Laboratory of Lichenology, W. Szafer Institute of Botany, Polish Academy of Sciences, Lubicz 46, 31-512 Krakow, Poland; e-mail: k.wilk@botany.pl

\section{INTRODUCTION}

The lichen genus Caloplaca s.l. is represented by 76 species in Poland (Wilk 2012; Szczepańska et al. 2013). Recent studies of calcicolous representatives of the genus from the Polish Carpathians have recognized several species new for Poland (Wilk \& Flakus 2006; Wilk 2011, 2012; Wilk $\&$ Śliwa 2012). Four more calcicolous species of Caloplaca s.1. new for the country are presented here: C. concreticola Vondrák \& Khodosovtsev, C. interfulgens (Nyl.) J. Steiner, C. isidiigera Vězda and C. scabrosa Søchting, Lorentsen \& Arup. They belong to different systematic groups: respectively, brown-black fruiting Caloplaca species, C. lactea gr., C. cerina gr., and C. crenularia gr. Brief taxonomic remarks and data on their habitat preferences and distribution are given.

\section{MATERIAL AND METHODS}

Material obtained from KRAM, KTC and the herbarium of Gorce National Park (GPN) was examined. Reference material from CBFS, KRAM, VU and MIN, including types, was consulted.

Morphology and anatomy were observed by standard techniques. Anatomical characters were measured from hand-cut sections and squash preparations mounted in water. Tissue granulation was observed under polarized light. The solubility of granules and/or crystals was tested with $25 \% \mathrm{KOH}(\mathrm{K})$ and $65 \%$ nitric acid $(\mathrm{N})$. $\mathrm{K}$ and $\mathrm{N}$ were used for color reactions and microscopy.

NomenClature. According to the most recent classification of Teloschistaceae (Arup et al. 2013), the recognized species belong to the following genera: Pyrenodesmia A. Massal. (C. concreticola Vondrák \& Khodosovtsev), Xanthocarpia A. Massal. \& D. Not. [C. interfulgens (Nyl.) J. Steiner] and Caloplaca Th. Fr. s.str. (C. isidiigera Vězda). For C. scabrosa Søchting, Lorentsen \& Arup and some of the other discussed species, however, there are no appropriate new combinations provided. Therefore, the traditional names for all these species were followed in this paper.

\section{THE SPECIES}

Caloplaca concreticola Vondrák \& Khodosovtsev Fig. 1

Lichenologist 40(2): 98. 2008.

This inconspicuous species has brown apothecia and a greyish areolate thallus. The areoles are flat and produce marginal bluish-grey soralia. The species is very similar to $C$. atroalba (Tuck.) Zahlbr. (for detailed description see Wilk 2011) but the latter has a slightly smaller, esorediate thallus, and its thalline cortex reacts violet with $\mathrm{K}$ due to 

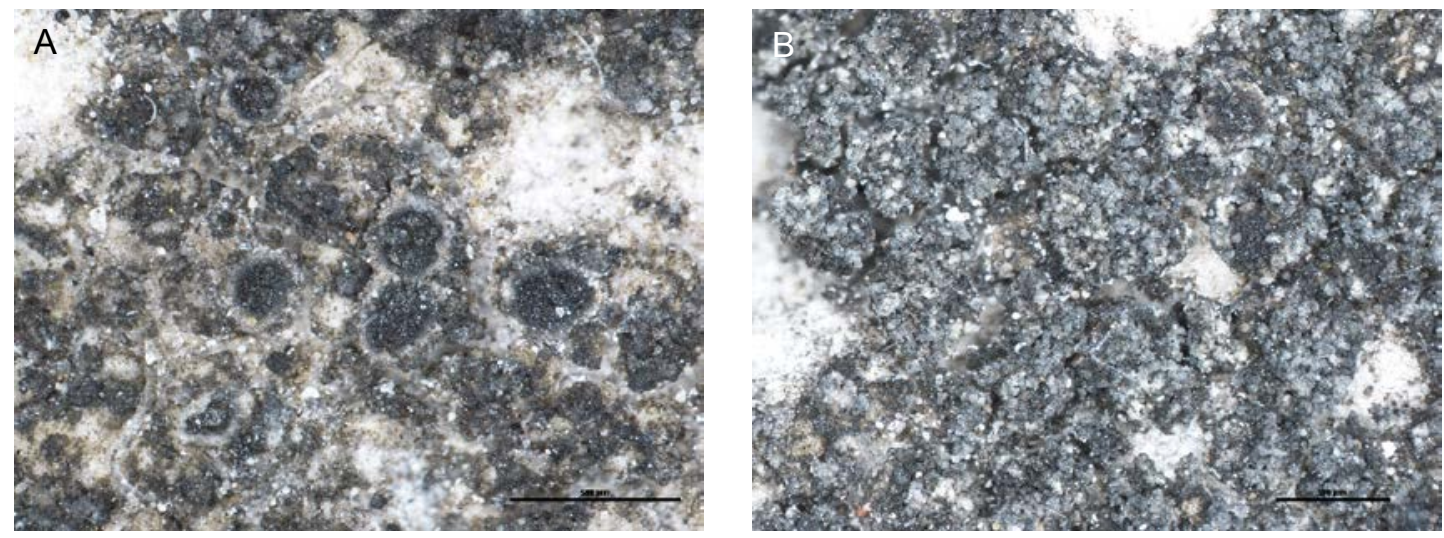

Fig. 1. Caloplaca concreticola Vondrák \& Khodosovtsev (I. Wrocławska \& K. Toborowicz s.n., KTC). A - thallus with apothecia, $\mathrm{B}$ - thallus with abundant soredia. Scale bars: A \& B $=0.5 \mathrm{~mm}$.

the presence of Sedifolia-grey pigment (the reaction is negative in C. concreticola). When sterile, $C$. concreticola can be confused with $C$. soralifera Vondrák \& Hrouzek, but the thalline cortex of the latter reacts violet with $\mathrm{K}$, similarly to C. atroalba (Vondrák et al. 2008a). Finally, C. pratensis Wetmore also is very similar to $C$. concreticola but differs in having convex areoles and soredia mostly on the upper surface of the areoles, and is known only from North America (Wetmore 2009). For a comparison with several other species see Vondrák et al. (2008a).

Caloplaca concreticola is known from Eastern and Central Europe and was recorded in Ukraine, Romania and Slovakia (Vondrák et al. 2008a). Most recently it was reported from Russia (Vondrák 2012), the Czech Republic, Asia (Kazakhstan) and also North America (USA) (Frolov \& Vondrák 2012; no exact localities are provided). The species occurs in dry, steppe and xerothermic habitats. It occupies anthropogenic substrates (e.g., concrete) as well as natural rocky substrates (calcareous sandstone).

In Poland the species was found in the Góry Świętokrzyskie Mts, where it grew on limestone among xerothermic vegetation.

SPeCimen EXAMINED. POLAND. Góry ŚwięTOKRZYSKIE MTs. Łysogórski district, Łagów, on limestone, 2 Aug. 1980, I. Wrockawska \& K. Toborowicz s.n. (KTC).

REFERENCE MATERIAL EXAMINED. Caloplaca concreticola: UKRAINA. KHERSONSKA OBLAST, CHAPLINSKIY
DISTRINCT, $c a 4.5 \mathrm{~km} \mathrm{~W}$ of Zaozerne village, Kakhovskiy water channel, alt. ca $30 \mathrm{~m}, 7$ June 2006, J. Vondrák \& J. Šoun (CBFS JV4636-holotype). Caloplaca pratensis: USA. North Dakota, Olivier Co., The Nature Conservancy's Cross Ranch Preserve, Sangor Ghost Town, alt. $515 \mathrm{~m}$, on old concrete foundation, 5 June 2007, M. K. Advita 6100 (MIN - holotype; Wetmore, Telos. Exsicc. 113, KRAM - isotype).

Caloplaca interfulgens (Nyl.) J. Steiner Fig. 2 Verhandl. Zool.-Bot. Gessellsch. Wien 52: 479. 1902.

The species is a member of the C. lactea group (Navarro-Rosinés \& Hladun 1996). It is a distinctive taxon having a yellow, well developed areolate to subsquamulose thallus. The species is similar

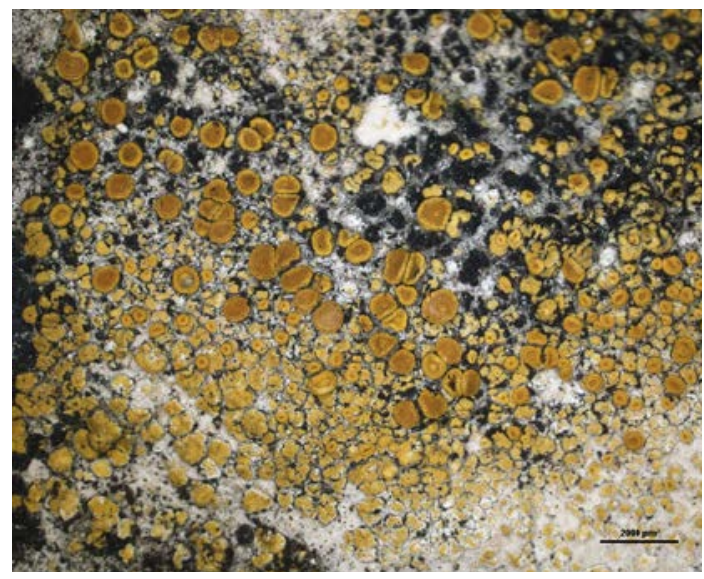

Fig. 2. Caloplaca interfulgens (Nyl.) J. Steiner (K. Wilk 3493, KRAM). Scale bar $=2 \mathrm{~mm}$. 
to $C$. crenulatella (Nyl.) H. Olivier but the latter has a less developed or even endolithic thallus producing no subsquamules at all. Moreover, the apothecia of $C$. crenulatella vary in color depending on the development stage (young apothecia are citrine-yellow; the old ones are dull yellow to orange), whereas in $C$. interfulgens the apothecia are uniformly orange (Navarro-Rosinés \& Hladun 1996). The recently described C. diffusa Vondrák $\&$ Llimona is very similar to $C$. interfulgens but differs from the latter in having an areolate thallus with a diffuse margin and a white or grey prothallus, and it occurs on siliceous rock (Vondrák et al. 2011).

In all examined specimens of $C$. interfulgens I observed a very well-developed thalline margin of the apothecia, whereas in the species description by Navarro-Rosinés and Hladun (1996) the thalline margin is specified as not macroscopically differentiated.

The species is known from the Mediterranean region, Middle East and Central Asia. Most recently it was also reported from Central and Eastern Europe. For its detailed distribution see Vondrák et al. (2013). The species occurs in desert, steppe and xerothermic habitats, occupying limestone rock (Navarro-Rosinés \& Hladun 1996; Vondrák et al. 2013).

In Poland the species is known from the Tatras and the Pieniny Mts, where it has been found on limestone in xerothermic habitats.

SPecimens eXamined. POLAND. Western CarPATHIANS. WeSTERn TATRA Mts, Dolina Chochołowska valley, Polana Chochołowska glade, alt. $1140 \mathrm{~m}$, on limestone rock, 1 Dec. 1995, J. Nowak s.n. (KRAM). PIENINY SPISKIE MTs, Pieniny National Park, Zielone Skałki range by Jezioro Czorsztyńskie lake, NE of Falsztyn, $49^{\circ} 25^{\prime} 56^{\prime \prime} \mathrm{N}, 20^{\circ} 17^{\prime} 35^{\prime \prime} \mathrm{E}$, alt. $588 \mathrm{~m}$, uppermost part of limestone outcrops, sunny place, 6 June 2005 \& 12 Nov. 2005, K. Wilk 3493 and 4139 (KRAM). Pieniny WŁaściwe Mts, Pieniny National Park, limestone outcrops by Czorsztyn Castle, $49^{\circ} 26^{\prime} 11^{\prime \prime} \mathrm{N}, 20^{\circ} 18^{\prime} 48^{\prime \prime} \mathrm{E}$, alt. $560 \mathrm{~m}$, on limestone, sunny place, $\mathrm{S}$ exposition, 5 June 2005, K. Wilk 3467 (KRAM). Male Pieniny MTS, near Jaworki village, Sołtysie Skałki outcrops, $49^{\circ} 24^{\prime} 24^{\prime \prime} \mathrm{N}, 20^{\circ} 32^{\prime} 29^{\prime \prime} \mathrm{E}$, alt. $617 \mathrm{~m}$, on upper parts of limestone outcrops, sunny place, 3 June 2005, K. Wilk 3387 (KRAM).
ADDITIONAL SPECIMENS EXAMINED. RUSSIA. LIPETSK REGION. Eletsky district, Eletsky Landscape Reserve, Dernovskiye Kichy site, $52^{\circ} 34.552^{\prime} \mathrm{N}, 38^{\circ} 21.203^{\prime} \mathrm{E}$, alt. $186 \mathrm{~m}$, on limestone rock, 5 July 2012, E. Muchnik s.n. (VU); Zadonsky district, Galichya Gora State Reserve, Galichya Gora site, $52^{\circ} 39.338^{\prime} \mathrm{N}, 38^{\circ} 59.410^{\prime} \mathrm{E}$, alt. $147 \mathrm{~m}$, on limestone rock, 30 June 2012, E. Muchnik s.n. (VU).

\section{Caloplaca isidiigera Vězda}

Fig. 3

Folia Geobot. Phytotax. Bohemoslov. 13: 417. 1978.

The species is a member of the C. cerina group, which is characterized by having a dark grey to blackish, areolate and isidiate thallus, and lecanorine apothecia with orange discs. No other saxicolous species of the group known in Poland produces vegetative diaspores such as isidia, lobules or granules. Among the other European 'isidiate' species of the group, C. squamuloisidiata van den Boom \& V. J. Rico and C. thracopontica Vondrák \& Šoun are the most similar to $C$. isidiigera. Caloplaca squamuloisidiata differs from C. isidiigera in having a pale grey and subsquamulose thallus, branched coralloid isidia (globose to shortly elongated or flattened in C. isidiigera), and it occurs on siliceous rock (Vondrák et al. 2008b; Šoun et al. 2011; Vondrák \& Wirth 2013). Caloplaca thracopontica differs from $C$. isidiigera in having a thallus producing pustules and lobules instead of typical isidia, and it occurs in maritime habitat on siliceous rock (Vondrák

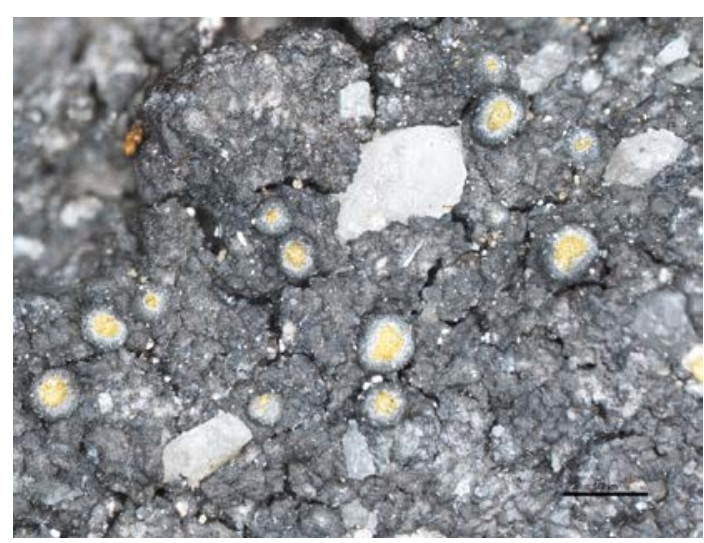

Fig. 3. Caloplaca isidiigera Vězda (P. Czarnota s.n., GPN). Scale bar $=0.5 \mathrm{~mm}$. 
et al. 2008b). Another species of the group that could be confused with $C$. isidiigera is $C$. chlorina (Flot.) H. Olivier, but the latter produces soredia or blastidia instead of typical isidia. The lecanorine type of apothecia in C. isidiigera is a good diagnostic character distinguishing the species from other unrelated but similar taxa such as C. conversa (Kremp.) Jatta, C. subpallida H. Magn. and C. xerica Poelt \& Vězda. They all form zeorine apothecia.

The species is confirmed from Europe (mainly the Alps and Carpathians) and North America (Šoun et al. 2011). It occurs in subalpine and alpine habitats on natural calcareous rock.

In Poland the species was found on calcareous sandstone in the Gorce Mts.

Specimen examined. POLAND. Western CarPAThians. Gorce Mts, Gorczański National Park, Polana Czoło glade, alt. $1260 \mathrm{~m}$, on calcareous sandstone, 14 Aug. 1999, P. Czarnota s.n. (GPN).

Caloplaca scabrosa Søchting, Lorentsen \& Arup Fig. 4

Nova Hedwigia 87: 89. 2008.

The species is a member of the $C$. crenularia group and is closely related to $C$. ammiospila (Ach.) H. Olivier and C. furfuracea H. Magn. (Vondrák et al. 2013). Caloplaca scabrosa is distinguished by its richly blastidiate, whitish thallus, and its biatorine red apothecia. The thallus contains

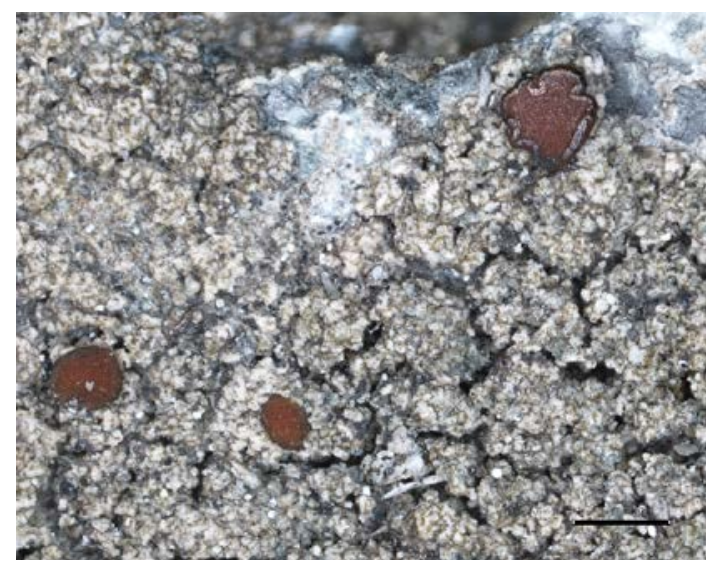

Fig. 4. Caloplaca scabrosa Søchting, Lorentsen \& Arup (A. Flakus 1889, KRAM). Scale bar $=1 \mathrm{~mm}$. atranorin, a lichen secondary metabolite rare in Teloschistaceae (Søchting et al. 2008). Caloplaca scabrosa is very similar to C. furfuracea but the latter differs in having a less blastidiate thallus lacking atranorin, and it occurs on wood or rarely on tree bark (Arup \& Åkelius 2009; Søchting et al. 2008), whereas C. scabrosa is epilithic. C. ammiospila is related to C. scabrosa but its thallus does not produce vegetative diaspores, it lacks atranorin, and it is muscicolous (Vondrák et al. 2013).

Caloplaca scabrosa was described from the Arctic (Svalbard). Most recently it was reported from the Czech Republic (Vondrák et al. 2013).

In Poland the species was found on limestone and mylonite rock in the Tatra Mts.

Specimens examined. POLAND. Western Carpathians. High Tatra Mts, Przełaczka pod Zadnim Mnichem pass, mylonite area, subnival belt, $49^{\circ} 11^{\prime} 19^{\prime \prime} \mathrm{N}$, $20^{\circ} 03^{\prime} 06^{\prime \prime} \mathrm{E}$, alt. $2135 \mathrm{~m}$, on mylonite rock, 16 Aug. 2003, A. Flakus 1889 (KRAM). West Tatra Mts, Rzędy, S slope of Ciemniak Mt., alt. ca 1800 m, 11 July 2004, K. Wilk 2090 (KRAM).

AcKnowledgements. I thank Martin Kukwa (Poland) and the anonymous reviewer for critical comments on the manuscript, the Curators of CBFS, GPN, KRAM, KTC, MIN and VU for loaning material for study, and Jan Vondrák and Ivan Frolov (Czech Republic) for constructive discussions and help with identification of $C$. isidiigera and confirmation of $C$. concreticola. Financial support was provided by the National Science Centre (NCN, grant no. N N303 821740).

\section{REFERENCES}

Arup U. \& Åkelius E. 2009. A taxonomic revision of Caloplaca herbidella and C. furfuracea. Lichenologist 41(5): $465-480$.

Arup U., Søchting U. \& FröDEN P. 2013. A new taxonomy of the family Teloschistaceae. Nord. J. Bot. 31: 16-83.

Frolov I. \& VondrÁK J. 2012. Black-fruting Caloplaca (Teloschistales, Ascomycota) in the steppe zone of the southern Ural Mts and surrounding areas. In: A. A. CHIBILEV (ed.), Steppes in northern Eurasia, pp. 770-773. Institut Stepi URO RAN \& Russkoe Geograficheskoe Obshchestvo, Orenburg (in Russian with English summary).

Navarro-Rosinés P. \& Hladun N. L. 1996. Les especies saxícolo-calcícolas del grupo de Caloplaca lactea (Teloschistacceae, líquenes), en las regiones mediterránea y medioeuropea. Bull. Soc. Linn. Provence 47: 139-166. 
Søchting U., LoRentsen L. B. \& Arup U. 2008. The lichen genus Caloplaca (Ascomycota, Lecanoromycetes) on Svalbard. Notes and additions. Nova Hedwigia 87(1-2): 69-96.

Šoun J., Vondrák J., Søchting U., HrouzeK P., KhodosovtSEV A. \& ARUP U. 2011. Taxonomy and phylogeny of the Caloplaca cerina group in Europe. Lichenologist 43(2): 113-135.

SzczepańsKa K., KossowsKa M. \& Wilk K. 2013. Caloplaca subpallida (Teloschistaceae), a lichen species new to Poland: Distribution, ecology and taxonomic affinities. Acta Soc. Bot. Poloniae 82(1): 85-89.

VONDRÁK J. 2012. Selected exsiccates of Caloplaca, Fasc. 3 (Nos 51-75). Fritschiana 74: 49-57.

Vondrák J. \& Wirth V. 2013. Caloplaca. In: V. Wirth, M. Hauck \& M. Schultz (eds), Die Flechten Deutschlands, pp. 262-317. Ulmer, Stuttgart.

VondrÁK J., Khodosovtsev A. \& ŘíHA P. 2008a. Caloplaca concreticola (Teloschistaceae), a new species from anthropogenic substrata in Eastern Europe. Lichenologist 40(2): 97-104.

Vondrak J., Říha P., Redchenko O., Vondráková O., HrouzeK P. \& Khodosovtsev A. 2011. The Caloplaca crenulatella species complex; its intricate taxonomy and description of a new species. Lichenologist 43(5): 467-481.
Vondrák J., Š́oun J., HrouzeK P., ŘíHa P., Kubásek J., PALiCe Z. \& Søchting U. 2008b. Caloplaca subalpina and $C$. thracopontica, two new saxicolous species from the Caloplaca cerina group (Teloschistales). Lichenologist 40(5): 375-386.

Vondrák J., Frolov I., Řiha P., Hrouzek P., Palice Z., Nadeyna O., Halici G., Khodosovtsev A. \& Roux C. 2013. New crustose Teloschistaceae in Central Europe. Lichenologist 45(6): 701-722.

Wetmore C. M. 2009. New species of Caloplaca (Teloschistaceae) from North America. Bryologist 112(2): 379-386.

WILK K. 2011. New or noteworthy records of Caloplaca (Teloschistaceae) from Poland. Mycotaxon 115: 83-98.

WILK K. 2012. Calcicolous species of the genus Caloplaca in the Polish Western Carpathians. Polish Bot. Stud. 29: 1-91.

WILK K. \& FlakUS A. 2006. Four species of Caloplaca (Teloschistaceae, lichenized Ascomycota) new to Poland. Mycotaxon 96: 61-71.

WiLK K. \& Ślıiwa L. 2012. Note on Caloplaca soralifera (Teloschistaceae, lichenized Ascomycetes) in Poland. Acta Soc. Bot. Poloniae 81(1): 61-63. 